\title{
PEMBELAJARAN SEJARAH DENGAN METODE DEBAT AKTIF UNTUK MENINGKATKAN MINAT BELAJAR SISWA DI KELAS X MIPA MADRASAH ALIYAH NEGERI 2 PONTIANAK
}

\author{
Eka Jaya Putra Utama', Agus Budi Nugroho \\ ${ }^{1}$ Program Studi Pendidikan Sejarah \\ Fakultas Ilmu Pendidikan dan Pengetahuan Sosial IKIP PGRI Pontianak \\ Jalan Ampera Nomor 88 Pontianak-78116, Telepon (0561) 748219 Fax. (0561) 6589855 \\ ${ }^{2}$ Madrasah Aliyah Negeri (MAN) 2 Pontianak \\ Jalan Jenderal Ahmad Yani Nomor 9 Pontianak-78121, Telepon (0561) 732795 \\ ${ }^{1}$ Alamat e-mail: ekajpu.ikipptk@gmail.com
}

\begin{abstract}
Abstrak
Tujuan penelitian ini adalah untuk mengetahui: (1) Perencanaan pembelajaran sejarah di kelas X MIPA Madrasah Aliyah Negeri 2 Pontianak, (2) Pelaksanaan pembelajaran sejarah di kelas X MIPA Madrasah Aliyah Negeri 2 Pontianak; dan (3) Peningkatan minat belajar sejarah dengan metode debat aktif di kelas X MIPA Madrasah Aliyah Negeri 2 Pontianak. Metode penelitian yang digunakan adalah penelitian tindakan dengan bentuk tindakan kelas kolaborasi. Subjek penelitian kelas X MIPA Madrasah Aliyah Negeri 2 Pontianak tahun ajaran 2018/2019 sebanyak 38 siswa. Teknik pengumpulan data yaitu melalui observasi, komunikasi tidak langsung, dan studi dokumentasi. Sedangkan alat pengumpul data berupa pedoman observasi, angket dan dokumen. Hasil penelitian ini menunjukkan bahwa penggunaan metode debat aktif dalam pembelajaran sejarah mendorong siswa menjadi kritis dalam berpendapat, kreatif untuk mengeluarkan ide gagasan di kelas dan meningkatkan minat belajar sejarah.
\end{abstract}

Kata Kunci: minat belajar sejarah, debat aktif.

\begin{abstract}
The purpose of this research was to find out about: (1) History lesson learning plan in class X MIPA Madrasah Aliyah Negeri 2 Pontianak, (2) Implementation of history learning in class X MIPA Madrasah Aliyah 2 Pontianak; and (3) Increasing of students interest in learning history with active debate methods in class X MIPA Madrasah Aliyah 2 Pontianak. The research method used action research with collaborative class action. Research subjects in class X MIPA Madrasah Aliyah Negeri 2 Pontianak 2018/2019 academic year as many as 38 students. Data collection techniques are through observation, indirect communication, and documentation study. Data collection tools are observation guide, questionnaires and documents. The results of this research indicate that by using active debate methods in historical learning encourages students to be critical in arguing, creative in issuing ideas in class and their interest in learning history were increased.
\end{abstract}

Keywords: interest in learning history, active debate.

\section{PENDAHULUAN}

Sistem pengajaran sebagai bagian integral dari sistem kegiatan pendidikan, merupakan fenomena yang harus diperbaiki dan dikembangkan oleh pihak-pihak terkait dan berkepentingan. Hal ini 
menyangkut kurikulum, metode, media pengajaran, materi pengajaran, kualitas pengajar, dan lain sebagainya sehingga tercipta sistem pengajaran yang baik dan berorientasi ke masa depan.

Dengan demikian perlu dikembangkan kegiatan pembelajaran yang berorientasi pada masa depan, dan menjadikan peserta didik tidak hanya sebagai objek belajar tetapi juga subjek dalam belajar. Seorang guru harus kreatif dan inovatif dalam merencanakan dan melaksanakan pembelajaran yang berpusat pada siswa (student centered) sehingga seluruh siswa terlibat aktif dalam pembelajaran.

Pembelajaran yang mendidik perlu diperhatikan bahwa guru sebagai pengajar tidak mendominasi kegiatan, tetapi membantu menciptakan kondisi yang kondusif serta memberikan motivasi dan bimbingan agar peserta didik dapat mengembangkan potensi dan kreativitasnya melalui kegiatan belajar. Fungsi guru sebenarnya adalah sebagai fasilitator atau memberikan fasilitas dan kemudahan bagi kegiatan pembelajaran peserta didik. Hal ini sesuai dengan prinsip mengajar yaitu untuk memberikan kemudahan dan memberikan motivasi bagi kegiatan belajar (Sardiman, 2006:2).

Salah satu metode pembelajaran yang tepat dan dapat digunakan dalam proses pembelajaran sejarah adalah metode debat aktif (active debate). Metode debat aktif termasuk dalam kategori pembelajaran aktif (active learning), yaitu pembelajaran yang melibatkan seluruh siswa di kelas. Secara umum debat adalah adu pendapat/argumen yang dilakukan oleh dua pihak baik perseorangan maupun kelompok, yaitu pro dan kontra. Melvin L. Silberman (2013: 27-28) keaktifan siswa dalam debat terlihat dari penyampaian argumentasi dan pertanyaan, keikutsertaan siswa dalam diskusi, memperhatikan jalannya debat, dan pengumpulan lembar penugasan.

Tujuan metode debat aktif ini adalah untuk melatih siswa berargumen yang kuat dalam memecahkan suatu permasalahan yang kontroversial serta memiliki sikap demokratis dan saling menghormati setiap pendapat yang berbeda. Muhammad Arif (2016: 72) moderator juga memberikan motivasi dan stimulus pada siswa agar siswa tidak kehabisan bahan pembicaraan, sehingga kecermatan 
moderator dalam memahami suatu topik dari berbagai sudut pandang sangat diperlukan.

Secara umum, hal yang lebih penting bukan terletak pada frekuensi bertanya siswa, melainkan kualitas pertanyaan siswa. Sejauh mana tingkat analisis dan pemikiran siswa dalam menghadapi suatu kasus permasalahan dapat dilihat berdasarkan pertanyaan siswa. Pengalaman dan pengetahuan yang dimiliki siswa juga berpengaruh terhadap kualitas pertanyaan siswa (Muhammad Arif, 2016: 73). Selanjutnya, menurut Ign. Marsidjo (1990:43) metode Active Debate merupakan sebuah metode dimana pembicara dari pihak pro dan kontra menyampaikan pendapatnya mereka masing-masing tetapi tidak ada yang kalah dan tidak ada yang menang.

Hasil observasi sebelum melakukan penelitian, menunjukkan bahwa peran siswa dalam pembelajaran pada dasarnya masih kurang. Hal ini disebabkan oleh ruang dan kesempatan yang diberikan oleh guru sedikit untuk mengaktifkan siswa. Sedangkan siswa untuk diikutkan dalam peran aktifnya sangat potensial. Dengan keadaan seperti itu maka perlu dilakukan penelitian di kelas X MIPA Madrasah Aliyah Negeri 2 Pontianak dengan menerapkan metode debat aktif (active debate) dalam kegiatan belajar mengajar. Penerapan metode debat aktif dalam pembelajaran di kelas diharapkan akan menumbuhkan kemampuan siswa untuk selalu kritis dalam menghadapi permasalahan, membuat suatu keputusan, dan berani menyuarakan apa yang ada dalam diri siswa baik ketika di lingkungan sekolah maupun di lingkungan luar sekolah.

Berdasarkan latar belakang di atas, penelitian ini bertujuan untuk meningkatkan minat belajar sejarah melalui metode debat aktif siswa kelas X MIPA Madrasah Aliyah Negeri 2 Pontianak. Secara umum rumusan masalah dalam penelitian ini yaitu "bagaimana upaya meningkatkan minat belajar sejarah dengan metode debat aktif di kelas $\mathrm{X}$ MIPA Madrasah Aliyah Negeri 2 Pontianak”.

Minat adalah suatu rasa lebih suka dan rasa keterikatan pada suatu hal atau aktifitas, tanpa ada yang menyuruh (Slameto, 2003:180). Sedangkan menurut 
Muhibbin Syah (2006:151) "minat (interest) berartikecenderungan dan kegairahan yang tinggi atau keinginan yang besar terhadap sesuatu”. Minat belajar adalah perasaan senang, suka dan perhatian terhadap usaha untuk mendapat ilmu pengetahuan. Dalam kegiatan belajar, siswa di sekolah mempalajari berbagai ilmu pengetahuan dan diusahakan agar semua siswa mendapatkan nilai yang bagus yang tentunya dapat dicapai dengan memiliki minat belajar yang tinggi.

Menurut Kuntowijoyo (2001:7) pengertian sejarah diibaratkan sebuah pohon karena hakikatnya ilmu sejarah selalu mengalami perkembangan. Sedangkan menurut Van der Meulen (dalam Isjoni, 2007:40) pembelajaran sejarah di sekolah bertujuan membangun kepribadian dan sikap mental anak didik, membangkitkan keinsyafan akan suatu dimensi fundamental dalam eksistensi manusia, mengantarkan manusia kejujuran dan kebijaksanaan pada anak didik, dan menanamkan cinta bangsa dan sikap kemanusiaan.

\section{METODE}

Jenis penelitian ini adalah penelitian tindakan kelas. Menurut Kemmis (dalam Rochiati Wiriaatmadja, 2014: 12), penelitian tindakan kelas adalah sebuah bentuk inkuiri refrektif yang dilakukan secara kemitraan mengenai sitiasi sosial (termasuk pendidikan) untuk meningkatkan rasionalitas dan keadilan. Lebih lanjut menurut Harjodiputro (dalam Anas Salahudin, 2015: 25), bahwa penelitian tindakan kelas adalah pendekatan untuk memperbaiki pendidikan melalui perubahan, dengan mendorong para guru untuk memikirkan praktik mengajar agar kritis terhadap praktik tersebut dan ada keinginan untuk mengubahnya.

Dalam penelitian ini kegiatan pembelajaran menggunakan metode debat aktif, sengaja untuk menumbuhkan kemampuan siswa kelas X MIPA dalam bertanya dan berargumentasi sehingga minat belajar sejarah dapat meningkat. Penelitian dilakukan secara kolaboratif dan partisipatif antara peneliti dengan guru mata pelajaran sejarah. Teknik pengumpul data dengan observasi langsung, komunikasi tidak langsung dan studi dokumentasi. Dengan alat pengumpul data lembar observasi, angket dan dokumen. 
Analisis data menggunakan analisis kualitatif untuk menggali informasi dari observasi dan dokumen, sedangkan analisis data kuantitatif untuk menentukan angka persentase minat siswa. Objek penelitian adalah minat belajar sejarah dengan metode debat aktif di Madrasah Aliyah Negeri 2 Pontianak. Sedangkan yang menjadi subjek dalam penelitian ini yaitu siswa kelas X MIPA Madrasah Aliyah Negeri 2 Pontianak sebanyak 38 siswa. Dalam penelitian ini menggunakan model Kemmis dan Mc Taggart yang terdiri dari empat tindakan, yaitu (1) perencanaan atau planning, (2) tindakan atau action, \& pengamatan atau observing, dan (3) refleksi atau reflecting (Suharsimi Arikunto, 2010: 131-132). Dengan pola siklus sebagai berikut:
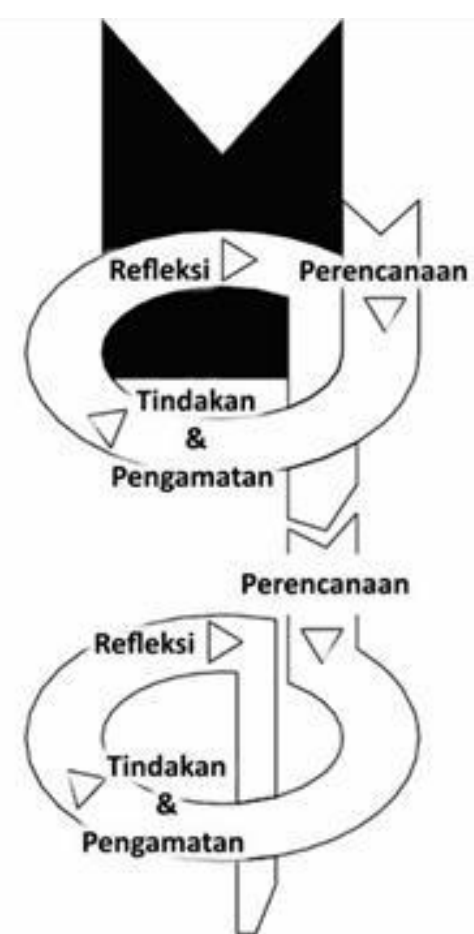

Gambar 1. Pola Siklus Tindakan Model Kemmis dan Mc Taggart

Perencanaan dilakukan untuk mempersiapkan segala sesuatu yang terkait dengan tindakan yang dilaksanakan di kelas X MIPA, yakni membuat rencana pembelajaran, memilih materi ajar, membuat media pembelajaran, menentukan jumlah siswa dalam kelompok dan diskusi dengan guru. Pada Tahap berikutnya merupakan penerapan dari isi rancangan yang telah disusun. Rancangan dalam bentuk rencana pembelajaran menjadi pokok utama dalam skenario pelaksanaannya. 
Pengamatan dilakukan pada saat tindakan sedang dilaksanakan. Pengamatan dan tindakan berjalan bersamaan dengan kolaborasi antara guru dan peneliti. Peneliti menggunakan pedoman observasi sebagai acuan untuk mengamati jalannya tindakan metode debat aktif dan kemampuan bertanya siswa.

Refleksi merupakan tahapan untuk mengemukakan kembali temuan dan mengevaluasi segala hal-hal yang sudah dilakukan. Hasil pelaksanaan tindakan yang telah diperoleh didiskusikan bersama dengan guru untuk melihat apakah ada peningkatan setelah tindakan dilaksanakan.

\section{HASIL DAN PEMBAHASAN}

Kegiatan belajar mengajar dapat berjalan dengan baik apabilaperencanaan disusun dengan baik dan strategi pembelajaran yangditerapkan sesuai dengan tujuan yang akan dicapai. Menurut Wina Sanjaya (2011:28-29) Perencanaan pembelajaran adalah proses pengambilan keputusan hasil berpikir rasional tentang sasaran dan tujuan pembelajaran tertentu, yakni perubahan tingkah laku serta rangkaian kegiatan yang harus dilaksanakan sebagai upaya pencapaian tujuan tersebut dengan memanfaatkan segala potensi dan sumber belajar yang ada. Hasil akhir dari proses pengambilan keputusan tersebut adalah tersusunnya dokumen yang berisi hal-hal di atas, sehingga dokumen tersebut dapat dijadikan sebagai acuan dan pedoman dalam melaksanakan proses pembelajaran.

Seorang guru harus memiliki kemampuan dalam merencanakan pembelajaran, karena kegiatan yang direncanakan dengan matangakan lebih terarah dan tujuan yang diinginkan akan mudah tercapai. Oleh sebab itu, seorang guru sebelum mengajar hendaknya merencanakan terlebih dahulu program pembelajaran, membuat persiapan pembelajaran yang hendak diberikan atau yang lebih dikenal dengan Rencana Pelaksanaan Pembelajaran (RPP). Kegiatan perencanaan dilakukan bersama dengan guru terutama dalam memilih dan menentukan strategi pembelajaran sejarah.

Berdasarkan observasi dan dokumen, pelaksanaan pembelajaran yang dilakukan terdiri dari dua tahap yaitu; tahap pra instruksional adalah tahapan yang ditempuh guru pada saat memulai proses belajar dan mengajar. Kegiatan yang 
dilakukan guru mata pelajaran sejarah pada tahapan sesuai dengan rencana pelaksanaan pembelajaran. Selanjutnya, tahap instruksional adalah tahap pengajaran atau biasa disebut dengan kegiatan inti. Pada tahap ini guru mata pelajaran sejarah menyampaikan tujuan pembelajaran dan penyajian materi. Isi atau materi pelajaran merupakan komponen kedua dalam sistem pembelajaran. Materi yang di ajarkan yakni kehidupan manusia purba dan asal-usul nenek moyang bangsa Indonesia (Melanesoid, Proto, dan Deutero Melayu). Dalam konteks tertentu, materi pelajaran merupakan inti dalam proses pembelajaran. Artinya, proses pembelajaran diartikan sebagai proses penyampaian materi yang diambil dari berbagai sumber.

Banyak hal yang terjadi terutama saat dengan metode debat aktif. Siswa menunjukkan kemampuannya masing-masing sesuai dengan tingkat pemahamannya pada materi pelajaran. Sehingga pada siklus pertama pembelajaran sejarah secara keseluruhan menunjukkan tingkat minat yang tinggi. Hal ini terbukti dengan tingginya antusias siswa ketika mengemukankan pendapat.

Namun ada sebagian siswa yang pendapatnya masih belum kuat dan berdasar. Tetapi paling tidak proses untuk meningkatkan minat belajar sejarah dengan metode debat aktif sudah memberikan pengaruh yang besar terhadap siswa secara kognitif untuk mengungkapkan pendapatnya. Dengan demikian dalam rangka untuk meningkatkan lebih tinggi maka perlu melakukan siklus berikutnya sehingga terjadinya peningkatan minat belajar sejarah.

Proses pembelajaran yang efektif, akan mengarah kepada pencapaian kompetensi. Proses pembelajaran sejarah dengan metode active debate, karena pada hakikatnya siswa akan mendapatkan pengetahuan, jika mereka mampu mengoptimalkan aktivitas belajarnya dengan perdebatan masing-masing siswa, baik aktivitas fisik maupun mental. Keaktifan siswa selama proses pembelajaran mempunyai pengaruh besar terhadap minat belajar yang akan dicapai.

Adanya penggunaan metode active debate dalam pembelajaran sejarah akan mendorong siswa dapat berpikir kritis, kreatif di kelas serta dapat meningkatkan minat belajar sejarah. Interaksi guru dan siswa menjadi penting. 
Kegiatan pembelajaran dengan menggunakan active debate dapat diwujudkan dalam bentuk belajar secara kelompok, diskusi dalam kelompok kecil belajar individu yang dilanjutkan dengan diskusi kelompok. Interaksi tersebut dapat diakomodasi antara lain melalui belajar kelompok yang heterogen.

Pada siklus 1 menunjukkan bahwa presentase angkat minat belajar sejarah sebesar 53,85\%, kemudian dilanjutkan pada siklus 2 sehingga terjadi peningkatan yang sangat signifikan yaitu $87,18 \%$. Hal ini berarti pada siklus 2 terjadi sebuah peningkatan yang menunjukkan bahwa proses dengan metode debat aktif sesuai pada prosedur, walau kericuhan tidak dapat dihindari pada situasi kelas yang jumlah siswanya besar.

Dari penjelasan di atas dapat diketahui bahwa adanya pembelajaran berbasis active debate dapat mendorong seseorang dalam mengembangkan dirinya untuk mendapatkan pengetahuan baru dengan kebebasan yang mereka miliki dan tidak terbatas hanya atas pemberitahuan dari orang lain. Dengan demikian hal ini mendukung pada proses pembelajaran dengan pendekatan active debate yaitu pendekatan yang memberikan kebebasan pada siswa untuk berfikir kritis mengenai sesuatu pada pembelajaran sejarah. Lebih lanjut bobot efektifitas penggunaan active debate dibandingkan penggunaan metode ceramah menempatkan penggunaan active debate jauh lebih efektif dibandingkan ceramah.

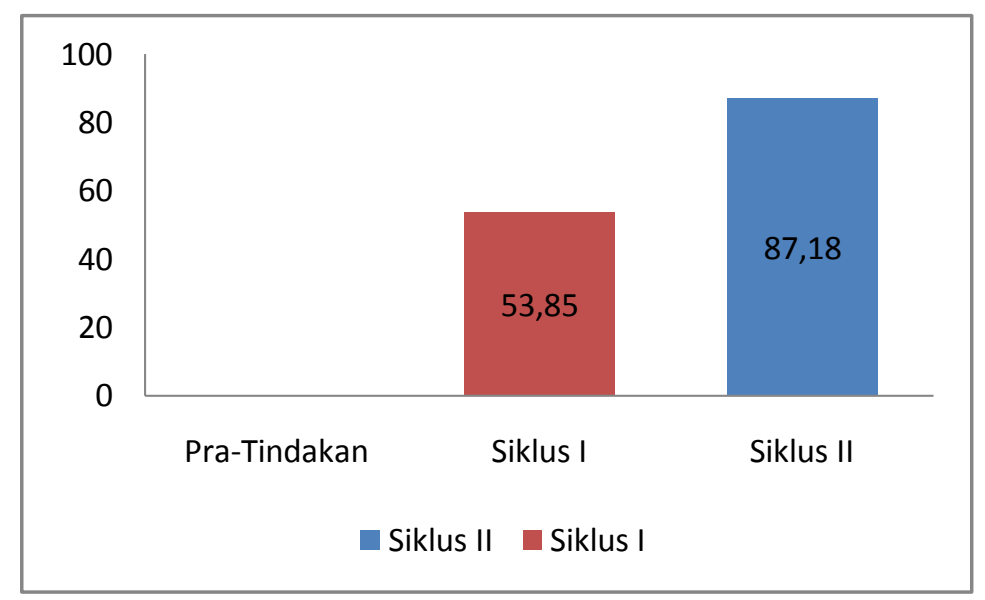

Gambar 2. Diagram Peningkatan Minat Belajar Sejarah Kelas X MIPA MAN 2 Pontianak TA.2018/2019 


\section{SIMPULAN}

Berdasarkan hasil analisis data penelitian, dapat ditarik simpulkan bahwa;

1. Perencanaan pembelajaran sejarah dilengkapi dengan perangkat pembelajaran yang dibuat sesuai dengan kebutuhan siswa dalam rangka untuk memberikan pemahaman lebih dalam pada siswa.

2. Dalam pelaksanaan pembelajaran sejarah, guru melakukan berbagai langkah yakni, apersepsi, eksplorasi, elaborasi dan konfirmasi, serta metode debat aktif yang diterapkan dalam pembelajaran sejarah. Efektivitas tersebut ditinjau dari peningkatan dalam keaktifan siswa menjadi lebih baik dari pada sebelumnya.

3. Selain itu hasil kajian empirik yang didukung oleh berbagai penemuan sebelumnya dapat membuktikan bahwa metode debat aktif dalam penelitian ini dapat digunakan sebagai metode yang dapat menunjang pembelajaran lebih efektif dan memiliki dampak positif.

Adapun saran yang dapat disampaikan sebagai berikut:

1. Bagi peneliti, membutuhkan waktu dan studi lebih lanjut dengan metode debat aktif yang berbeda untuk mengatasi berbagai permasalahan pembelajaran yang terjadi di kelas, sehingga akan lebih menyempurnakan penelitian ini.

2. Bagi sekolah, fasilitas memadai yang dimiliki sekolah akan sangat mendukung terlaksananya metode debat aktif di sekolah.

3. Bagi guru, perlu banyak inovasi dan kreatif dalam memilih metode dalam strategi pembelajaran sejarah untuk mengembangkan potensi yang ada pada siswa. Selain nilai memang penting bagi guru, namun proses belajar jauh lebih penting bagi siswa, karena melalui proses itulah siswa akan belajar.

4. Bagi siswa, diharapkan menjadi aktif untuk bertanya, dan meningkatkan keberanian serta menghilangkan rasa takut dalam bertanya, berbicara ataupun berpendapat, dengan demikian akan membangkitkan minat belajar sejarah lebih tinggi.

\section{DAFTAR PUSTAKA}


AM Sardiman. 2006. Interaksi dan Motivasi Belajar Mengajar. Jakarta: Raja Grafindo Persada.

Arif Muhammad, 2016. Peningkatan Kemampuan Bertanya Melalui Merode Debat Aktif Siswa Kelas VIII D SMP N 2 Banguntapan Bantul. Jurnal Prodi Teknologi Pendidikan Vol. V Nomor 5 Tahun 2016.

Arikunto Suharsimi. 2010. Prosedur Penelitian Suatu Pendekatan Praktik. rev.ed.Jakarta: Rineka Cipta

Kuntowijoyo. 2001. Pengantar Ilmu Sejarah. Yogyakarta; Bentang Budaya.

Marsidjo Ign. 1990. Kapita Selekta Psikologi Pendidikan. Yogyakarta: Universitas.

Isjoni. 2007. Pembelajaran Sejarah Pada Satuan Pendidikan. Bandung: Alfabeta.

Salahudin Anas. 2015. Penelitian Tindakan Kelas. Bandung; CV.Pustaka Setia

Sanjaya Wina. 2011. Perencanaan dan Desain Sistem Pembelajaran. Jakarta: Kencana

Silberman, Melvin L. (2013). Active Learning:101 Cara Belajar Siswa Aktif. Bandung: Nuansa Cendekia.

Slameto. 2003. Belajar dan Faktor-Faktor Yang Mempengaruhinya. Jakarta; Bina Aksara.

Syah Muhibbin. 2006. Psikologi Pendidikan. Bandung; Remaja Rosdakarya.

Wiriaatmadja Rochiati. 2012. Metode Penelitian Tindakan Kelas. Bandung: PT.Remaja Rosdakarya. 